\title{
OLD TESTAMENT PENTECOST
}

DT Williams

Theology

Fort Hare

\begin{abstract}
Just as modern Charismatics seek to justify the reality of their experiences by appealing to Acts 2, so the validity of the experience of Acts 2 itself needs justification from Old Testament parallels. A neglected passage in this regard is Numbers 11, where the elders of Israel were given from the spirit that was on Moses, and then prophesied. This story can function as a legitimation of the story of Acts 2, and can then throw light on its meaning. The modern claims of the receipt of the Spirit may then be tested against the features of both passages.
\end{abstract}

\section{Introduction}

The growth of Pentecostal, Charismatic, and most recently, "third wave" groups and churches, has been one of the most striking features of the twentieth century. Since the outbreak of Pentecostal experiences especially in a small meeting at Azusa Street in Los Angeles in 1906, such groups have grown at a dynamic rate, quite eclipsing that in the existing denominations, and indeed often contributing to a general decline in their numbers. The reaction of Christians to this movement has been mixed. On the one hand, some have regarded the claims of the movement as spurious, human induced, or possibly even demonic. On the other hand, others have accepted the new emphasis with enthusiasm, becoming a part of what they see as a genuine movement of the Holy Spirit. They usually see their experience in terms of a repetition of what happened at Pentecost.

The nature and meaning of the event recorded in Acts 2 when the Holy Spirit descended on the small group of disciples at Jerusalem, with the associated phenomena of wind and fire and especially the following manifestation of the so-called gift of "tongues", is therefore still a matter for intense debate. Could it have been spurious, a reaction emanating from the subconscious minds of a group of people unbalanced by the trauma of the preceding weeks? But if it was genuine, how far is it to be repeated in the experience of groups and individuals of the later Church; is there a personal "Pentecost", a real "baptism of the Spirit"?

It is possible to go some way towards answering such questions by looking at the phenomenon of Pentecost in its context. Of course, the disciples were waiting for something to happen because Jesus at his ascension had told them to, and because at his farewell discourse recorded in John 14-6, he had prepared them for the coming of the Spirit. It is interesting that this "prediction" of the coming of the Spirit did not include some hint of the dramatic nature of Pentecost, such as the wind, fire and tongues. The author of the fourth gospel could be deliberately downplaying the external phenomena; it is sometimes suggested that he saw the initial filling by the Spirit in very different terms, giving his version in John 20:22, where Jesus breathed on the disciples (cf Turner 1996:89f for a discussion of this issue.) However, this was not all, but just as the understanding of Jesus is enhanced by seeking to understand him and his work against the background of the Old Testament, such as fulfilling the office of prophet, priest and king, as indeed the New 
Testament suggests, as in the book of Hebrews, so Pentecost also has its precursors.

In fact, the events at Pentecost were so dramatic that Peter immediately had to justify them, which he did in a way appropriate to his audience by reference to the Old Testament. It was not an unprecedented event. As is well-known, he described what happened as a fulfilment of the prophecy of Joel, quoting it in his sermon, albeit with a small but quite significant addition, "and they shall prophesy". What he does not do is connect the supposed fulfilment with the context of Joel, for without this the connection could be viewed as arbitrary. Even if there is a possible connection, such as a fruitful harvest unaffected by predators, this was not reported as having been made by Peter.

Some have been surprised that Pentecost was not immediately interpreted against the confusion of languages at Babel (Gen 11). It is attractive to understand the events of Jesus' passion, resurrection and then Pentecost as the answer to the sin which was judged at Babel. However, Marshall (1977:366) aptly comments that if this was the case, languages would have been reversed, which was not so. Also, the understanding of other languages would have been more permanent. It may even be suggested that the later experience of tongues, which seems to be different from that in Acts 2, even adds to the confusion of languages! More importantly, the stress would then fall on tongues, which is really a side issue to the essential feature, which was the descent of the Spirit. The Spirit is not even mentioned at the Babel event, not even by means of phenomena often associated with him, such as fire and wind, which might have been expected at such a judgement.

It must be highly significant that the events occurred when they did, at the feast of Pentecost. Just as the death of Jesus must be understood as fulfilling the Passover, so as an event of salvation, so also the events of fifty days later. Here the Old Testament does not provide very much help, celebrating the feast of Weeks, which included Pentecost as a harvest festival (Ex 23:15). Certainly a harvest interpretation is appropriate, for what happened at Pentecost may be interpreted as a harvest into the new movement. It can also be seen as the gift of new life. Later Judaism, at least by New Testament times, also included the idea of a commemoration of the giving of the Law at Sinai (Cole 1979:179). Witherington (1998:131) believes that the connection was made much earlier; it is hardly surprising in view of the timing of the events. Certainly it was the Elders who generally dispensed justice (De Vaux 1973:152). Lüdemann (1989:41) comments that the redactional themes in Acts 2 parallel Sinai. Philo's description of Sinai (Decal 32-49) describes the voice of God becoming a flaming fire (Marshall 1977:354). This introduces the key element of the activity of the Spirit, and makes a connection with the phenomena at Pentecost. The link is also appropriate as one function of the Spirit is the internalisation of the Law (Jer 31:31f, Heb 10:15f). It is also significant insofar as the Pentecostal event authenticated leaders not provided for in the law, so complemented it.

But Pentecost was more than just a fulfilment of a prophecy, and more than a fulfilment of a repeated festival. To better understand what happened, it is necessary to look for precedents of the descent of the Spirit. Here the baptism of Jesus does provide one, but the circumstances are fairly different and the phenomena are outwardly dissimilar. Another possible precedent is at the translation of Elijah and the associated gift of the Spirit to Elisha (2 Ki 2). More similarity can be seen, such as an associated ascension, where Elijah parallels Jesus, and even an appearance of fire, but the two events are still hardly comparable.

It is much more productive to look far further back in the Old Testament to an event 
which is quite striking in its similarity to Pentecost. The events of Numbers 11 , where it is recorded that God took some of the spirit that was on Moses, and gave it to the elders so that they could help him, and their subsequent experience, are on all accounts dramatic. This is one of the earliest references to the Spirit, and only the third where a person is empowered. It is the first place where the Spirit is connected with prophecy; in fact references to earlier prophets are limited to Genesis 20:7 (Abraham), and Exodus 7:1 (Aaron). In neither case is there any indication as to how the gift manifested. What is even more striking is that this is rarely referred to as a justification for Pentecost! (The connection is made by a Jewish author, Milgrom (1990:383), and by Allen (1990:794).) Nevertheless, by looking at the features of the event, light can hopefully be shed on the meaning of the Pentecostal event, and then more relevantly for Christians today, on the claim of so many that they have personally experienced a repetition of the event in their own lives.

\section{Uniqueness}

Classical Pentecostal theology understands the "second blessing" as a unique event in the lives of those experiencing it. Just as conversion occurs once for salvation, so this also occurs once for empowering. Here one of the striking features of the Numbers narrative is its uniqueness; in particular, although they prophesied, "they did not do so again" (Num 11:25).

There is a little disagreement on this point. The Authorised Version translates "and did not cease", implying a continued exercise of the gift. Most modern translations, and many commentators (eg Ashley (1993:214)), however prefer a sense such as New International Version "but they did not do so again", although they often do note the alternative possibility. The latter better reflects the Hebrew (Noth 1968:89) as well as the Septuagint; the former comes from the Targums and Vulgate (Kennedy [sa]:253). Stuttgartiensis observes a textual variant, but prefers an interpretation that sees the event as unique, citing the parallel of Deut 5:22, where this interpretation is demanded by the context.

There is no indication that prophesying was part of the continued role of the elders, but belongs totally to the start of this role as Moses' helpers, so having his authority. For this purpose, a unique experience, just as in a prophetic call, would be adequate; this then sees the prophesying as an authentication or witness (Du Bois 1969:480). In this case, the tongues of Acts 2 can probably be understood in the same way. Acts 2 is then unique, which explains the differences from the phenomena of 1 Corinthians, and indeed of today. Presumably the Spirit did remain on them for their ministry, although there is no account of how they operated, in what way the Spirit enabled them, unlike the stories of the wisdom of Solomon, also presumably Spirit-given. There is then no suggestion that reliable judgements can only be delivered in ecstasy; there would be no need for any trance state or ritual accompanying the actions of eldership.

\section{Legitimation?}

Just as the descent of the Spirit on Jesus at his baptism functioned as designating him as Son of God, and as John said, showing his authority (Matt 3:12), so the Pentecostal experience designated those on whom the Spirit fell. The addition that Peter made to Joel's words, "and they shall prophesy" (Acts 2:18) may be taken as his claim to speak with the authority of God since the Spirit had fallen on him. Likewise John 20:22, whether or not it 
refers to an actual giving of the Spirit at that time, links it with the authority given to those who received the gift. Numbers 11 is also clearly about the authority given to the elders to share Moses' role.

Nevertheless, it seems unlikely that the purpose of the Pentecostal experience was the legitimation of a group of leaders. Rather the passage almost stresses the point that the Spirit fell on a large group, and on all who were in the house. Peter's citation of Joel likewise indicates the wider compass of the gift. Peter may have spoken as the accepted leader, but he did not have sole authority. Rather all who receive the Spirit also receive a role for which the Spirit equips them, the rationale behind the idea of "body ministry" so beloved in Charismatic circles. This would seem to be the case also in Numbers 11. The gift is limited to Israel, but not to a smaller group within it. Not only was the Spirit given to a group who did not need legitimation because they already had authority as elders, but reference to the role of the elders is conspicuously absent from the story in which the giving is recorded. Rather the connection would seem to be that just as God empowers physically in the gift of food, so he also empowers for service.

The seventy could well be seen as representing all Israel. This is the same as the number of those recorded as having gone down to Egypt (Ex 1:5). It could also be a reference to the seventy nations of Genesis 10, which would support a wider representation. There was also a tradition (Shab 88b) that the law was originally given in the seventy languages of the whole world (Marshall 1977:349). Admittedly the number does occur elsewhere in reference to governing councils, eg Jud 9:5, $2 \mathrm{Ki}$ 10:6, and of course ultimately in the number of the Sanhedrin (Milgrom 1990:87), but this may well flow from this passage.

Burns (1983:239) suggests that the story is an attempt to legitimate the later adoption of Canaanite ecstasy by Israel. Similarly, Noth (1968:90) suggests that "Eldad and Medad" represent later groups who sought acceptance. However, the differences between the two phenomena make this unlikely. In particular there is no evidence that the experience of Numbers 11 was induced or repeated, both features of the Canaanite practice. It is also very unlikely that any passage in the Old Testament could be intended to approve a set of beliefs which the Old Testament as a whole condemns, particularly as later thought saw the adoption of Baalism as a prime cause of the exile.

A related view is that of Sturdy (1976:86), who sees the climax of the story in Numbers 11:29. He sees it as an attack on those who resisted a general right to prophesy. Again this is perhaps unlikely in view of the non-repetition of the experience. More importantly, it is hardly likely that the account would then confine the practice to those specifically appointed. The Old Testament view is rather that prophecy is restricted to those specifically called, as in the case of later prophets such as Jeremiah. Even the more "ecstatic" phenomena are usually practised only in a defined group; when Saul prophesied, the immediate question was, "who is their father?" (1 Sam 10:12).

It is possible that the writer intended to justify the existence and authority of a permanent body of elders. Thus Knierim, cited by Childs (1974:324), sees the passage as legitimating civil judges, as referred to in Deuteronomy 19:15f. Eichrodt (1967:54) says that the attitude of $\mathrm{E}$ was that political leaders had to be men of the Spirit, an assessment repeated by Budd (1984:130) of the Yahwist. He contrasts P's view that the Spirit was linked to the office, so could be transferred, such as by laying on of hands, citing Deut 34:9 and 1 Sam 16:13. Nevertheless, he writes that it is a "methodological error to argue from 
these late passages to the original conception of endowment with the Spirit (cf Jepsen, Nabi, p33)". Certainly, as in other societies, there was such a body, and in Israel they had continued influence, even in the monarchy (eg $2 \mathrm{Ki} 23: 1$ ); of course after its fall, and the cessation of prophecy, their influence could be less threatened, and indeed the New Testament reflects their continuing role.

It was the existence of the judges, authenticated by their charisma, the kings, by their anointing, and the priests and Levites, by heredity, which could perhaps have threatened the role of the elders. All of the other roles were prophetically authenticated, so this could be an attempt to do the same for the elders as an ongoing institution.

Nevertheless, the explanation of legitimation is subject to some objections. Firstly the authority of elders, as based on age and on the fact that the body was already there, should not need justification. Secondly, justification of such a body would be expected to include an indication of a mode of succession, a feature absent from Numbers 11. Thirdly, the prophesying is a strange method of authentication, as it seems unrelated to their role in government; it also can only authenticate those who actually prophesy. It is also hard to understand why it was once, unless to explain why elders at a later date did not prophesy. Fourthly, the affair of Eldad and Medad does not readily fit this explanation. However, Milgrom (1990:90) records a tradition that six elders came from each tribe, but lots were taken to restrict the total to seventy; Eldad and Medad were then those excluded. (Why the two were not with the others is not actually explained. It has also been suggested that they were modest, or ceremonially unclean (Jamieson et al 1961:120); Hirsch (1964:184) and Kennedy ([sa]:253) also suggest the former. Of course, there could be any number of reasons.)

However, even if it would seem unlikely that the text is intended to legitimate a continuing office of elders, the incident could still do just that for those at the time. Indeed, some (eg Jamieson et al 1961:119) believe that the appointment could be just for the crisis of the time. Particularly the prophesying could be seen as a proof of the reality of the relationship with the Spirit, and so as an authentication of the authority of those particular elders (Keil \& Delitzsch 1865:70). Again, however, the lack of reference in the context perhaps mitigates against this.

\section{Transfer}

The New Testament account emphasizes that the Spirit was not given until Jesus had ascended (Jn 7:39), and that he would be "another Paraclete" (Jn 14:16). He is the Spirit of Jesus (Acts 16:7), replacing him, and acting in his place. The Old Testament event is described in similar terms of God moving some of the Spirit from Moses to the Elders. They can then act for him, and so share his burden.

It is of course possible that "spirit" here is Moses' spirit, not God's; "spirit" can refer to a human quality, such as drive or motivation. Ashley (1993:211) however points out that the word is generally used of God's, and that mighty deeds are generally attributed to him. In any case, the quality of Moses' spirit would be due to the action of God's Spirit. This would mean that the elders were inspired by God to emulate Moses. This was emphatically not just a descent of the Spirit onto them directly from God, but involved Moses as the intermediary. There is no indication in the Bible as to how Moses himself received the Spirit, although it may well be suggested that this was at the experience of the burning bush (Ex 3), with its manifestation of fire, often symbolizing the Spirit, as in Acts 2. 
In fact Moses was an intermediary in a different sense, in that the seventy were chosen by Moses out of a wider body (Num 11:16, Levine 1993:328). These would be those who shared Moses' desires, or "spirit", so what God's Spirit did was to ratify Moses' choice and to enhance what was already present.

In Numbers 11, however, there is no indication of any action on Moses' part; he would seem to be entirely passive in the matter. It is not a sacramental transfer. This is of course particularly the case for Eldad and Medad (Milgrom 1990:87). However, even if Moses did not actually do anything, the implication is that the elders are sharing his authority and ability. At the same time, because the gift was not given through him, it is seen as by God's prerogative; this makes it not transferable to any others, such as later elders.

Neither is there any indication of any attendant circumstances; there was no ritual, no service of worship, no music, in short nothing is recorded as having been done to change the emotional state of the Elders to make them more ready to receive the Spirit. Nothing whatever is said about their preparation, which contrasts with the fact that the people are told to prepare themselves for the gift of food, even if this is not likely to be understood as ritual purification (Levine 1993:324). The emphasis falls on the divine initiative; neither donor nor recipient was active.

It need not be supposed that Moses was unwilling to share the leadership, despite Ashley's interpretation of Numbers 11:14-5 and 21-2 (1993:216); Milgrom (1990:86) feels that the emphatic "I" of Numbers 11:14 indicates his desire to share. His meekness can rather be seen as a sign of strength (Budd 1984:130). Indeed, Moses protested at the burden of sole responsibility, "Did I conceive all these people?" (Num 11:12), a complaint which was answered in the distribution of the Spirit (Burns 1983:228). However, he did not share the leadership, but only some of the work that his role entailed. It may however be observed that when the "spirit of wisdom" was given to Joshua (Deut 34:9), which was an "ordination" to leadership, it was by the laying on of Moses' hands. Later Jews then presumed that he had in fact done the same for the elders (De Vaux 1973:347), but this in unwarranted. The role of elders, and that of the leader, may be distinguished. "Body ministry" is not corporate leadership, but shared service.

The language used in many translations is indicative of quantity, implying that after the event, Moses had less of the Spirit than before. Similar language of quantity is used in the parallel event of the transfer of the spirit of Elijah to Elisha, where the request is for "a double portion" (2 Ki 2:9). Incidentally, Milgrom (1990:86) believes that the story of Elijah, such as including a death wish, was modelled after that of Moses. Of course, this is only the request, and the reality may well not be the same; it may also be figurative, insofar as a double portion was the right of the first-born (Deut 21:17). Rabbi A $h$ a is also recorded as saying that the Spirit was given, even to the prophets, "by measure" (Turner 1996:59). Thinking in terms of quantity still occurs today, such as with the suggestion (Olson 1996:68) that the Spirit "spilled over" to the two away from the tent, or with Sturdy (1976:85), that Moses had so much that it could be shared. A New Testament comment is in John 3:34, "it is not by measure that he gives the Spirit". In this case, the transfer would be a violation of his authority (Maarsingh 1987:42); however, the taking only from the Spirit on Moses can mean that he retains pre-eminence (Sakenfeld 1995:76); Moses remains the only one with whom God communicates directly (Davies 1995:105). Such "face to face" communication is described in Exodus 33:7-11, a story which Budd (1984:129) believes is linked to Numbers 11 by the mention of Joshua. Incidentally, 
Sakenfeld (1995:76) denies that Moses displeased God, unlike the people, but rather that his words of complaint indicate a deep ongoing relationship, as in the "psalms of lament". There is then no implication of a loss of Moses' position, indeed the standing of the elders is dependent upon his continued authority. They do his work, but only with his ability and authority.

Such language need not however necessarily indicate quantification, seeing the spirit in material terms so that it was inconceivable that something could be taken without diminishing what remained. Something like wisdom, which is actually often identified with, or seen as a gift of, the Spirit, can clearly be shared without loss (Milgrom 1990:87). Particularly if "spirit" means drive or motivation, this in no way makes the spirit material. Keil \& Delitzsch (1865:70), although they note that Calvin saw the event as a signum indignationis or nota ignominias for Moses, point out that a flame actually grows by division; they suggest that this relief would then strengthen Moses' natural ability, so "spirit".

"Take from", which comes from the Septuagint, is in any case not the best rendering of the Hebrew 'sl, which is better understood as "join with", or "share", which avoids the problem, as it means only that the elders were equipped in the same way as Moses to share his role. The noun 'asil is consistent with this, as it means a leader (Snaith 1967:229-30). This then reinforces the authority of the elders in the community; at the same time it must quash any temptation on their part to support any action against Moses.

\section{Coming upon}

The account of Pentecost describes the coming of the Spirit onto the disciples. The symbols of wind, and more particularly of fire, stress an external origin. They were not filled from within, but from without.

At Pentecost, the Spirit came upon them (but in Acts 2:4 then filled them). The word "upon" (epi) is characteristic of all initial experiences (Acts 2:3, 8:16, 10:44, 19:6, even Matt 3:16, Jn 1:32, but not of an abiding state eg Rom 8:9, 1 Cor 3:16). Marshall (1977:352) understands baptism as a deluge from above; however he feels that all the terms for the gift of the Spirit (baptism, falling on, filling) should be taken as equivalent (1977:356). Perhaps the analogy of Frost (1971:39) is helpful; he refers to the idea of a ship sinking in its "baptism", when it is full of water; this could well happen when it is deluged from above. In this case, filling is the result of the descent from above; this need not however imply that the state is permanent.

It may then be observed that the Spirit was not in Moses, but upon ( $l$ ) him, and likewise then upon the Elders (Num 11:25, 29). The same expression is used in Numbers 24:2 of Balaam, and then in Isaiah 61:1; in the Septuagint and in Luke 4:18, this is translated as epi. Micah 3:8 however refers to being full of power by the Spirit. The latter expression is comparatively rare, the majority of occurrences in both Testaments using "upon".

Hirsch (1964:179) makes a distinction between the two by suggesting that the Spirit works in a person to increase a natural capacity, but comes upon a person to enable what cannot naturally be done, such as prophecy. This would explain the prophesying, but not the reason for the transfer, which was presumably the enhancing of judgemental ability, a natural gift. If Hirsch is correct, it may also be expected that the Spirit would be in, rather than upon, Moses. It could be validly suggested that entirely the opposite is the case, that 
the coming of the Spirit upon a person would increase a natural endowment.

It is possible that the expression connotates the initiation of a relationship; in later theology, Augustine saw the Spirit as bonding. It may be observed that in general, "coming upon" is used of an initial experience, filling for the result, as in the case of Bezalel (Ex 36:30), Joseph (Gen 41:38), or even Joshua, after Moses' hands had been laid on him (Deut 34:9). It could be objected that this is not consistent, as the Spirit is upon Moses even in Numbers 11, comes upon people on occasions subsequent to an initial experience (frequently in Judges and 1 Samuel, and in Ezekiel 3:24). However, "being full" need not necessarily preclude an experience of the Spirit also "coming upon".

The externality of the experience perhaps does not imply the compulsion that filling would give, so preserves the absolute freedom of the one receiving the Spirit. This contrasts with the sense of compulsion experienced by such as Jeremiah (Jer 20:9). However, the roles of prophet and leader are not the same, the former being completely dependent upon divine inspiration. Another possibility is that "coming upon" stresses the non-permanent endowment with the Spirit.

\section{Visibility}

The symbols of Acts 2, like the dove on Jesus, provided a visible indication of what had occurred. It was not just a subjective experience.

What the expression of "coming upon" may well also imply is that the event is a clear, nonsubjective phenomenon, such that the presence of the Spirit is then obvious, and the status of the recipient is unquestioned. Packer (1995:204f) believes that the book of Acts chooses to describe the descent of the Spirit in Samaria (Acts 8), on the household of Cornelius (Acts 10) and on the disciples of John (Acts 19) because each is a significant set of circumstances. The Spirit is shown, in an observable way, to descend on each significant group. In contrast, the normal Christian experience would not be so dramatic. Indeed, it may well be suggested that as the normal Christian experience is salvation by faith, without external verification, so the endowment with the Spirit would also be unobtrusive.

\section{Covenant}

The Acts account does not specify the location of the experience, even if tradition locates it in the upper room, no doubt sacred to the disciples from the memory of the last supper. What it does stress is that the disciples were together, and it may be inferred that the group was exclusively those who were disciples, such was their fear after the events of the previous weeks. The gift of the Spirit was limited to the parties of the "new covenant".

The events of Numbers 11 were an experience of a group of people, the elders, who already had a position in Israel. The experience did not occur to an undesignated body. This is exactly what is understood by Pentecostal theology in relation to the "baptism in the Spirit", the "second blessing", which is experienced by people who are already Christians. It is not an initiatory experience.

Even if there was no specific action on the part of Moses, the location of the transfer was specified. The seventy elders were told to assemble at the tent of meeting (Num 11:16). It is stressed that it was God who did the actual transfer, not Moses, and so it was appropriate that it took place in the place where God customarily met with the people. The gift is then an intensification of God's meeting with them. Nevertheless, the fact that Eldad and Medad also received the gift, although they were not in the tent, would indicate that the 
specific location was not totally essential. This indicates again that there is no sacramentalism in the event.

What the location does do is to put the endowment with the Spirit firmly in the context of the on-going relationship, the covenant, between God and Israel. It is then an aspect of that relationship, which means that eldership is performed only in its context.

The difference between what was outwardly a very similar event of delegation in Exodus 18, and the one in Numbers 11 , is that between the two came the enacting of the covenant and the associated giving of the law. On the one hand, the relationship between God and the elders, as part of Israel, was enhanced, but on the other, the basis of the practice of their leadership in the law was given. Following Driver (1911:163), McNeile (1911:61) suggests that Exodus 18 has been misplaced from after the giving of the law, but this seems unlikely; it is based on the presumption that the wilderness referred to in Exodus 18:5 refers to one only reached at a later stage.

\section{Service}

At the ascension, when Jesus sent the disciples back to Jerusalem to wait for the gift of the Spirit, that was firmly placed in the context of the reason for the gift, the witness of the disciples to the world. Likewise Paul's discussion of the charismata in 1 Corinthians places it firmly for the same purpose. The gift was for service.

The giving of the Spirit to the elders was not a purposeless event, or even for the experience and benefit of the elders themselves, but emphatically so that they were able to help Moses better. Far from being blessed, the elders would be burdened; here it is noteworthy that the prophetic "office" is often described as a burden (eg Hab 1:1), indeed one that the prophet would often love to be rid of. The transfer was then for the benefit of Moses, to take some of the burden away from him. If "spirit" is interpreted in the sense of motive or pressure, sharing this would indeed lighten the burden on him (Allen 1990:794). More specifically, the gift was for the benefit of the entire community. The essence of this was so that the murmuring and unrest of the people would be resolved, in short, that the community would operate in a harmonious way.

Ferguson (1996:22) notes that the role of the Spirit is often to give order, so is appropriate for government. This ties in with the understanding of the Spirit as generating relationship, even if the prophesying, as in Corinth, perhaps initially had the opposite effect! Moses' desire was that all would receive the Spirit (Num 11:29); this indeed indicates a solution to the problems in any society, as government becomes superfluous if all were perfect. The fact of a gift limited to a few reflects a different attitude to society, preserving absolute freedom of human choice; this then demands structure and leadership. Moses' wish also reflects a desire to welcome insights of people outside the number of institutional leaders. Incidentally, Snaith (1967:233) sees the openness of Moses as consistent with the theology of E, while the restriction desired by Joshua that of $\mathrm{P}$; he believes that these represent the two fundamental types of religion, inclusive and exclusive.

The account of the gift of the Spirit is in the context of a specific crisis in the experience of Israel, and it may be presumed that if that crisis had not occurred then, the gift of the Spirit would not have occurred at that point either. Naturally, the account has been split into J and E sources (eg McNeile 1911:61f, or Noth 1968:83), thereby separating the incidents. Noth comments that it is hard to separate the sources, although he does see the incident as a prophetic insertion into the story of the quails (also Budd 1984:126). It 
may be observed that the answer to the problems of the people was not only by the coming of the Spirit (Heb ruach) on the elders, but by the blowing of the wind (Heb ruach) which brought the quails. Wenham (1981:109) and Milgrom (1990:376f) also believe that the events are linked. It may also be noted that the prophecy of Joel, which includes the section quoted by Peter on the day of Pentecost, was also in the context of a specific food crisis, in that case devastation of crops by locusts.

It is probably because of its purpose that the gift of the Spirit was limited to the leaders, and indeed it would seem that only a limited number of them, seventy, received the gift. The recipients were then those who were already in a position of leadership in the community. The gift enhances a role already performed, not initiates something new. Already in Exodus 18:13f, on the advice of Jethro, Moses' father-in law, there had been a measure of delegation of the responsibility of leadership, but the gift of the Spirit would seem to have been the occasion for an enlargement of their role. [Some, eg Budd (1984:126) however attribute Exodus 18 to the Elohist, but Numbers 11 (and Exodus 33 711) to the Yahwist, so separating them.] The complaint, to which provision of the quail was part of the solution, brought the issue of leadership to a head (Budd (1984:131).

\section{Theophany?}

As already noted, the relation between John 20:22 and Acts 2 is still much debated. Perhaps what is significant for the former is that it was an appearance of the resurrected Jesus, with an obvious manifestation of divine power. He was able to enter through locked doors, and if the experience of a week laterwas similar, showed deity. Then on the mount of ascension, the disciples also witnessed the divine side of his nature. It was in the context of these events that Pentecost occurred.

For the elders themselves, the experience of Exodus 24:9-11 was probably more significant than the preceding covenant. The elders, presumably the same group, had gone up into the mountain, and personally witnessed God. (Milgrom (1990:87) denies that the groups were the same. Olson (1996:67) records a Rabbinic tradition that the first group perished in the rebellion at Taberah (Num 11:1-3). Du Bois (1969:479) however identifies them.) This was a part of the enactment of the covenant, but it did not include the empowering of the elders at that time; indeed it is specifically stated that he did not "lay his hand" on them (Ex 24:11). In contrast, the account of Numbers 11 does not record any theophany more than the cloud, which was observed by all the people. In the light of the subsequent prophesying of the elders, the specific theophany of Exodus 24 is significant, as it is generally, more likely always, the case that the call of a prophet was authenticated by a theophany.

As in the case of the later prophets, the elders could then be assured of their role and authority. It is also then noteworthy that at their commissioning in Numbers 11, the fact that God spoke with Moses, which was in the hearing of the elders, was stressed. Specifically, the experience enabled them to recognise the voice of God guiding their ministry. Again, the prophets received the "word of the Lord" to be passed on; it was appropriate that a ministry that would essentially be vocal included an audible element at its commencement. As with the prophets, they were not given regular dramatic experience, but could rely on what had happened to them at the start of their ministry. 


\section{Prophesying}

The aspect of Pentecost, both in Acts 2 and in the contemporary church, that still occasions the most debate is the experience of glossolalia, "speaking in tongues". It is probably the feature that is of the most significance for those who experienced the Spirit, as well as those who witnessed it.

Even if the theophany to the elders was the most significant event for them, and served to authenticate their role for them, what then occurred, the prophesying of the elders, including Eldad and Medad, must have been the most significant for the people, establishing the authority of the elders in the community. Smeaton (1974:21) thus sees this as an act of accreditation. (The Shepherd of Hermas refers to a book by Eldad and Medad, presumably an account of their prophesying (Davies 1995:110).)

The narrative is too brief to understand the nature of the experience, but the fact that the Hithpael rather than the Niphal of the verb is used (Num 11:25,27) would suggest that what happened was not so much the communication of rational oracles, as with the later prophets, but more akin to ecstasy, perhaps similar to what occurred with the later "sons of the prophets". (Wilson (1979:329f) discusses the use of the two forms and suggests that they carried different meanings in least some period of Israel's history. Hirsch (1964:183) concurs with this distinction, observing the use of the Niphal for "serious" prophecy. It must be noted, however, that some, such as Ashley (1993:213) see no difference in meaning in the use of the two forms of the verb.) Wenham (1981:109) goes so far as to identify the speaking, and the later experience of Saul, with the gift of "tongues". Incidentally, Moses' desire that all prophesy (Num 11:29) uses the Niphal.

In both Numbers 11 and Acts 2, the experience was involuntary. There is no indication of any desire to prophesy in any sense, but it would seem that the experience simply occurred even without any suspicion of what would happen. The case of Eldad and Medad would also exclude any theory of a psychologically induced phenomenon; there was no suggestion involved. Whereas the others, being at the tent, may well have been open to something happening, this could not have been the case for those not there. Even if they were on the way, they would at most have expected something to happen only on their arrival. This is really also the case with the others; although they may well have expected something, there is no recorded precedent which could be imitated, even subconsciously. Again this aspect strengthens the point that the authority of the elders was divinely given; they were not self-appointed.

The manifestation of speaking was resisted by some at the time. It is perhaps significant that the one who is reported to have done so, possibly among others, was Joshua, at that point Moses' servant. (One tradition also has it that the young man who reported to Moses was Gershom (Snaith 1967:232).) It is usually the case, as with later prophecy in the Old Testament, that it often failed to be accepted by representatives of the established order, such as rulers and priests. This is likely to be the case as existing leaders have a vested interest in stability, which could well be shaken by any occurrence of such a nature. There has always been tension between institutional and other leaders, such as the later prophets (Sakenfeld 1995:76). It has commonly been a human reaction to try and control or organise the supernatural, whether by seeking, as here, to stop its activity except in an acceptable way, or to use it, as in magic, or in such as Baalism, the enhancement of fertility by religion.

It may possibly even have been resisted by the elders themselves, although there is no 
indication of their own reaction to what happened. Perhaps this could even explain the absence of Eldad and Medad. In this case there is much more of a parallel with other call narratives of the Old Testament, which almost uniformly include the unwillingness of those being called (cf Habel 1965).

\section{Conclusion}

For Christians, the story in Numbers 11 must immediately be of interest due to the similarities with the events on the day of Pentecost (Acts 2). Particularly if Moses is seen as a precursor of Christ, an identification made elsewhere in the New Testament, the parallels are strikingly exact. There was a preceding "theophany", and a preceding enactment of covenant. There had even been a meal, in the upper room, a location consecrated to God. There was a gift of the Spirit of the leader (Jn 15:26), whose death had thrown the group into crisis, a commissioning of a pre-chosen group for service, but without any ritual or liturgy. The result of this was involuntary and unexpected prophesying, resisted by some, in a way that does not seem to have been repeated later; the differences between Acts 2 and 1 Corinthians are quite marked (Blaiklock 1959:55). Obviously the parallels are not completely exact, but are so near as to be breath-taking.

An interpretation of Acts 2 as a parallel to Numbers 11 can then provide suggestions as to the meaning of the latter. Particularly if both of them are unique initiation events, it could indicate that neither the elders of Numbers 11 nor those on whom the Spirit fell in Acts 2 have any direct successors. As much of the Church has said, the office of apostle was not intended to be self-perpetuating; doubt may also be thrown on a continuing office of "elder". If such eldership is accepted, however, a Pentecostal experience would not justify it as a ruling function, but only for service.

For many Christians, Acts 2, and so also Numbers 11, are of even greater importance. Such are those who claim to have received a personal experience of the Holy Spirit, often accompanied by the "gift of tongues". Although this claim and gift are today so widespread, there is still a strong desire to justify it, both to a sceptical world and to an often suspicious Church. It is here that the parallels between the two accounts are particularly significant, for there are differences from later experience. There is rarely any hint of theophany, often specific laying on of hands for a pre-desired and expected gift, often wanted not so much for service, or in any context of crisis, but for personal benefit, albeit in enhanced worship. Then usually the essence of the "prophesying" is that it is frequently repeated.

Such does not in any way cast doubts on the validity and value of a personal Pentecost, but only indicates that where there is doubt about the genuineness of this experience, it cannot really be justified by appeal to Acts 2 or Numbers 11 (and probably not even to 1 Corinthians (Packer 1995:207)!). Nevertheless, both events do contain a desire for, and indications of, a more widespread gift of the Spirit (Num 11:29, Acts 2:38). Ferguson (1996:63) sees a fulfilment of Moses' wish at Pentecost, but in fact prophecy has always been a limited gift. Indications of validity may however be found elsewhere, for example by parallels with Acts 8, where the Spirit was given through the laying on of hands (perhaps here for leadership; the gift was significantly given again without this in Acts 10). It is probably best seen in the results of the experiences in the lives of individuals and community. As Jesus said, "you shall know them by their fruits" (Matt 7:16). 


\section{BIBLIOGRAPHY}

Allen, RB 1990. Numbers. Gaebelein, FE (ed.) The expositor's Bible commentary vol 2. Grand Rapids: Eerdmans (Regency).

Ashley, TR 1993. The book of Numbers. Grand Rapids: Eerdmans.

Blaiklock, EM 1959. The Acts of the Apostles: an historical commentary. London: Tyndale.

Budd, PJ 1984. Word Biblical commentary vol 5: Numbers. Waco, Tx: Word.

Burns, RJ 1983. Exodus, Leviticus, Numbers. Wilmington, Delaware: Michael Glazier.

Childs, BS 1974. Exodus: a commentary. London: SCM.

Cole, RA 1979. Exodus: an introduction and commentary. London: InterVarsity.

Davies, EW 1995. Numbers. Grand Rapids: Eerdmans / London: Marshall Pickering.

De Vaux, R 1973. Ancient Israel: its life and institutions. London: darton, Longman \& Todd.

Du Bois, LJ 1969. Numbers. Beacon Bible Commentary vol 1 Kansas City: Beacon Hall.

Driver, SR 1911. The book of Exodus. Cambridge: University press.

Eichrodt, W 1967. Theology of the Old Testament vol 2. London: SCM.

Ferguson, SB 1996. The Holy Spirit. Downers Grove, Ill: InterVarsity.

Frost, RC 1971. Aglow with the Spirit. rev ed. Plainfield, N J: Logos International.

Habel, N 1965. The form and significance of the call narratives. Zeitschrift für die Alttestamentliche Wissenschaft 77, 297-323.

Hirsch, SR 1964. The Pentateuch vol 4: Numbers. 2nd ed. London: Isaac Levy.

Jamieson, R, Fausset, AR \& Brown, D 1961. Commentary practical and explanatory on the whole Bible. rev ed. [sl]: Oliphants.

Keil, CF \& Delitzsch, F 1865. Biblical commentary on the Old Testament. vol III: the Pentateuch. Edinburgh: T \& T Clark.

Kennedy, ARS [sa]. Leviticus and Numbers. Edinburgh: TC \& EC Jack.

Levine, BA 1993. Numbers 1-20: a new translation with introduction and commentary. New York: Doubleday (Anchor Bible).

Lüdemann, G 1989. Early Christianity according to the traditions in Acts: a commentary. London: SCM.

McNeile, AH 1911. The book of Numbers. Cambridge: University press.

Marshall, IH 1977. The significance of Pentecost. Scottish Journal of Theology 30(4) 34769.

Maarsingh, B 1987. Numbers: a practical commentary. Grand Rapids: Eerdmans.

Milgrom, J 1990 (5750). The JPS Torah commentary: Numbers. Philadelphia / New York: The Jewish publication society.

Noth, M 1968. Numbers: a commentary. London: SCM.

Olson, DT 1996. Numbers. Louisville: John Knox.

Packer, JI 1995. Keep in step with the Spirit. Leicester: IVP.

Sakenfeld, KP 1995. Journeying with God: a commentary on the book of Numbers. Grand Rapids: Eerdmans/Edinburgh: Handsel.

Smeaton, G. 1974 (1889). The doctrine of the Holy Spirit. Edinburgh: Banner of Truth.

Snaith, NH 1967. Leviticus and Numbers. London: Nelson. 
Sturdy, J 1976. Numbers. Cambridge: Cambridge University press.

Turner, M 1996. The Holy Spirit and spiritual gifts then and now. Carlisle: Paternoster.

Wenham, GJ 1981. Numbers: an introduction and commentary. Leicester / Downers Grove, Ill: Inter-Varsity.

Wilson, RR 1979. Prophecy and ecstasy: a reexamination. Journal of Biblical Literature 98 321-37.

Witherington, B III 1998. The Acts of the Apostles: a socio-rhetorical commentary. Grand Rapids: Eerdmans/Carlisle: Paternoster. 